\title{
Soil reconstruction after mining fails to restore soil function in an Australian arid woodland
}

\author{
Corrine Duncan ${ }^{1 *}$, Megan K Good ${ }^{2}$, Ian Sluiter ${ }^{1}$, Simon Cook ${ }^{1}$, and Nick L Schultz ${ }^{1}$ \\ ${ }^{1}$ School of Health and Life Sciences, Federation University, Mount Helen, VIC 3350, Australia. \\ ${ }^{2}$ BioSciences, University of Melbourne, Parkville, VIC 3052, Australia. \\ * Corresponding author email: corrineduncan@students.federation.edu.au
}

Running title: Soil reconstruction in an arid woodland \begin{abstract}
interpretation of results, provided critical feedback and helped frame the manuscript.
This is the author manuscript accepted for publication and has undergone full peer review but has not been through the copyediting, typesetting, pagination and proofreading process, which may lead to differences between this version and the Version of Record. Please cite this article as doi: $10.1111 /$ rec.13166
\end{abstract}

Author contributions: CD developed the theoretical foundations, conducted all experiments and took lead in writing the manuscript; CD, NS, MG developed the methods and analysed the data; IS described soil profiles and texture; all authors verified the methods, supervised the

This article is protected by copyright. All rights reserved. 
This article is protected by copyright. All rights reserved. 


\begin{abstract}
The biogeochemical properties of soils drive ecosystem function and vegetation dynamics, and hence soil restoration after mining should aim to reinstate the soil properties and hydrological dynamics of remnant ecosystems. The aim of this study is to assess soil structure in two vegetationtypes in an arid ecosystem, and to understand how these soil properties compare to a reconstructed soil profile after mining. In an arid ecosystem in southeast Australia, soil samples were collected at five depths (to $105 \mathrm{~cm}$ ) from remnant woodland and shrubland sites, and sites either disturbed or totally reconstructed after mining. We assessed soil physico-chemical properties and microbial activity. Soils in the remnant arid ecosystem had coarse-textured topsoils that overlay clay horizons, which allows water to infiltrate and avoid evaporation, but also slows drainage to deeper horizons. Conversely, reconstructed soils had high sand content at subsoil horizons and high bulk density and compaction at surface layers $(0-20 \mathrm{~cm})$. Reconstructed soils had topsoils with higher $\mathrm{pH}$ and electrical conductivity. The reconstructed soils did not show increased microbial activity with time since restoration. Overall, the reconstructed soil horizons were not organised in a way that allowed rainfall infiltration and water storage, as is imperative to arid-zone ecosystem function. Future restoration efforts in arid ecosystems should focus on increasing sand content of soils near the surface, to reduce evaporative water loss and improve soil quality and plant health.
\end{abstract}

This article is protected by copyright. All rights reserved. 
Keywords: Arid zone restoration, biochemical properties, inverse texture, microbial biocrusts, soil profile, topsoils.

\section{Implications for Practice}

- The aim of soil reconstruction of an arid-zone ecosystem after mining should be to replicate hydrological dynamics of the remnant ecosystem, which is closely linked to the organisation of soil horizons.

- In arid systems, coarse-textured upper horizons overlying clay subsoils may be essential to increase infiltration, reduce evaporation and prevent water loss through deep drainage.

- Practitioners should understand the hydrological dynamics and organisation of soil profiles of their reference ecosystems, and monitor how well this is replicated in their reconstructed soil. 


\section{Introduction}

Land degradation and desertification are major global socioeconomic and environmental issues (Wang 2004). Restoration of degraded arid zones is particularly challenging due to low and variable rainfall (Pickup \& Stafford Smith 1993). Despite enormous efforts, restoration success in arid ecosystems is low (Cortina et al. 2011; Ravi et al. 2010). Restoration is often complicated by nutrient-poor skeletal soils, erosion from wind and water, and a sparse distribution and cover of slow-growing plant species (Kassas 1995) which makes these ecosystems more sensitive to disturbance, and more challenging to restore than ecosystems with higher rainfall (James et al. 2013). As we improve our understanding of the processes governing arid-zone ecosystem functioning, we must ensure that we incorporate this understanding into our restoration efforts.

Water is the major limiting resource for growth and productivity in arid zones (Noy-Meir 1973) because rainfall is low and evaporation is generally higher than rainfall across all months (Houston 2006). As such, the physical properties of arid-zone soils, such as compaction, bulk density, clay content and horizon thickness, directly influence infiltration and evaporation (Simmers 2003). According to the Inverse Texture Hypothesis (Noy-Meir 1973), arid vegetation is more productive in coarse-textured soils than fine-textured soils due to less evaporative water loss (Noy-Meir 1973; Sala et al. 1988). Conversely, high bulk density and fine-particle content at deeper soil horizons prevents water leeching

This article is protected by copyright. All rights reserved. 
below the maximum rooting depth of plants. Consequently, any disturbing process that alters soil texture and reorganises soil horizons can impact the soil’s ability to resist water loss, and can negatively impact plant growth (Cleverly et al. 2016).

In mining landscapes, soils that are reconstructed after mining often have transformed soil chemical and physical profiles (Sheoran et al. 2010) with lower nutrient availability and higher bulk density, pH and electrical conductivity (Shrestha \& Lal 2011). These soil properties are crucial to soil-water balance and distribution of plant species in arid zones (Huang et al. 2017). Poor storage of topsoil can cause significant erosion and soil loss (Golos \& Dixon 2014). Additionally, significantly altered soil physico-chemical properties in reconstructed soils can further influence resource dynamics, ecosystem productivity (Muñoz-Rojas et al. 2016), and the ability of native species to adapt to local conditions (Griscom \& Ashton 2011). Given the importance of soil properties to the establishment and survival of arid plants (Austin et al. 2004), quantifying the effects of soil reconstruction may provide insights to enhance restoration outcomes in arid zones.

Clearing vegetation and stripping topsoils changes the soil microbiome, a critical factor for plant fitness and diversity in arid zones (Lau \& Lennon 2012; Moreira-Grez et al. 2019). Microbial activity in biocrusts is important for soil stability, nutrient cycling and moisture retention 
(Lau \& Lennon 2012). Recovery of microbial crusts on bare soil is incredibly slow and may require hundreds of years to fully recover (Belnap \& Eldridge 2001). Microorganisms have varied responses to soil amendments, and some taxa exhibit significant positive changes with amendments of water and organic matter, while other taxa decline (Buelow et al. 2016). Likewise, microbial responses to disturbance vary widely amongst taxa and further studies are required to understand how the scale of disturbance can impact the distribution and recovery of microbial populations in arid soils.

There is a growing recognition of how biotic components of arid ecosystems influence ecosystem function; for example, a high cover of vascular plants can improve ecosystem productivity and soil fertility, creating positive feedback loops (Maestre et al. 2016). Furthermore, the importance of biotic attributes to soil properties tends to increase as environmental stress or aridity increases (Maestre et al. 2010). Considering vegetation cover can exert significant influences on the biogeochemistry of arid soils, we might expect correlations between above ground cover, soil properties and ecosystem function (Johnson et al. 2016). Feedbacks between vegetation cover, soil fertility and ecosystem function can be positive or negative (Johnson et al. 2016) and are still poorly understood (van der Putten et al. 2013). 
The aim of the study was twofold: (1) to assess soil properties in a natural arid ecosystem, and (2) to understand how soil properties important for plant growth are impacted by severe disturbance and soil reconstruction. Based on the prediction that changes to soil physical, chemical and biological structure can impede plant recovery and inhibit growth of trees and shrubs (Schwinning \& Sala 2004; Sheoran et al. 2010), we test the hypotheses that reconstructed soils differ from the undisturbed remnant soils in properties important for plant growth, specifically in the distribution of particle-size content, nutrients and microbial activity.

\section{Methods}

\section{Study area}

The study site was $30 \mathrm{~km}$ west of Pooncarie in south-eastern Australia’s arid zone (33²2’S, $142^{\circ} 13^{\prime} \mathrm{E}$ ) at the Ginkgo Mine, a mineral sands mine. Mining commenced in 2006 and will conclude in 2020, although rehabilitation will continue beyond 2020. The study area is a hot desert climate, according to the Koppen Classification System. Mean annual rainfall was $250 \mathrm{~mm}$ (BOM 2018), although annual rainfall often falls below $200 \mathrm{~mm}$ for consecutive years (Environdata 2019). Mean annual temperature is $18^{\circ} \mathrm{C}$, although temperatures can range from $48^{\circ} \mathrm{C}$ to $-3^{\circ} \mathrm{C}$ (BOM 2018). Evaporation rates (mean $5.6 \mathrm{~mm} \cdot \mathrm{hr}^{-1}$ ) are higher than rainfall across all months (Environdata 2019). Soils of the study area are 
Pleistocene age aeolian deposits of the Woorinen Formation and arranged mostly as plains (Lawrence 1966), but also occur as east-west aligned dunes and swales. Prior to mining, soils are predominantly Calcarosols (Isbell \& NCST 2016) with surface soil textures of plains dominated by sandy clay loam and clay loam, with subordinate dune areas often characterized by light sandy clay loam and sandy loam. Subsoil B-horizons are ubiquitously characterized by carbonate pedoderms with elevated calcium carbonate content. Soils of rehabilitation areas are Anthroposols (Isbell \& NCST 2016). Native shrubs have been successfully established in rehabilitation areas, but successful establishment of tree species has been negligible (Sluiter \& Schultz 2017).

\section{Site selection}

In this study, we selected sites in three types of soil profiles that remain after mineral sand mining, each of which is subject to ecological restoration: (1) mine path sites, where soils have been removed, stored and replaced with reconstructed subsoil and topsoil; (2) overburden sites; raised structures where subsoil and topsoils were reconstructed over excess rock fragments; and (3) soil stockpile sites where soils were temporarily stored, and then removed, leaving a degraded area requiring restoration (Fig. 1). The mine path and overburden sites were considered as reconstructed soil profiles herein. In the soil stockpile sites, only the surface layer has been disturbed and hence these sites will be 
considered separately. Mine path and overburden sites were reconstructed by spreading a minimum of $20 \mathrm{~cm}$ subsoil and $20 \mathrm{~cm}$ of topsoil prior to seeding (Fig. 1). Restoration activities (including direct-seedling with a mix of native plant species) occurred in four years in overburden sites (2009, 2011, 2012 and 2013), and in three years in mine path and soil stockpile sites (2014, 2015, and 2017). Ten sites were selected in the mined area (three mine path, four overburden and three soil stockpile). Five remnant shrubland sites and five remnant woodland sites were also selected from around the study area for comparison to the mine sites, providing a total of 20 sites.

\section{Vegetation of the study area}

The two dominant broad vegetation community types are (a) woodlands dominated by belah (Casuarina pauper) with a bluebush (Maireana spp.) understorey shrub layer; and (b) chenopod shrublands primarily dominated by Maireana species. Shrubs were observed across all sites, although shrubs were typically smaller at woodland sites. The shrub layer of the vegetation is dominated by either Maireana pyramidata or M. sedifolia, and seldom both. These species are long-lived perennials which grow to $1.5 \mathrm{~m}$ (Walsh 1996) and in the case of M. sedifolia, may live for centuries (Crisp 1978). Other common perennial chenopod shrubs present include Maireana georgei, M. turbinata and M. trichoptera and Atriplex spp., including A. vesicaria and A. stipitata. Only the woodlands featured tree and grass species, and these sites were dominated by the 
tree Casuarina pauper and the perennial grass Austrostipa nitida. Both of these species were absent from rehabilitation sites. The most common ground flora species across all sites was the short-lived perennial herb, Sclerolaena obliquicuspis. The most prolific weed across all sites was Ward's weed (Carrichtera annua) which was more prevalent in the reconstructed ecosystems. Current vegetation structure at the reconstructed sites was more similar to shrubland than woodland sites, despite broadcasting significant quantities of tree and grass species.

\section{Soil description}

Soil profiles of remnant and rehabilitation sites were described using the Australian Soil Classification (Isbell \& NCST 2016), by excavating a pit with a backhoe to $1.5 \mathrm{~m}$ depth. At each pit site, all soil horizons were identified using the following criteria: soil texture, colour, pedality (type and grade), field $\mathrm{pH}$, readily available water at maximum root zone depths (herein referred to as available water) and carbonate reaction type. Topsoil depth at all sites was determined as the depth of the A horizon. Soil samples were collected from all sites by scraping soil from the pit face with a small pick hammer at depths of 0-10 cm, 10-20 cm, 25-45 cm, 55-75 cm and 85-105 cm. Soil samples were stored at $4^{\circ} \mathrm{C}$ upon collection, and until processed and analysed. All soil samples were collected during the 21st - 23rd of February 2018. 


\section{Biophysical and chemical properties of soils}

Samples were collected using a 10-cm corer hammered into the pit face at five depths (5, 15, 35, 65 and $95 \mathrm{~cm})$. To measure bulk density, gravimetric soil-moisture and soil porosity according to Carter \& Gregorich (2007), soil samples were oven dried at $105^{\circ} \mathrm{C}$ until soil mass remained constant. The structural stability of soil aggregates was measured using the Emerson (1967) test. Slaking was noted after 1 minute and 1 hour, and dispersion was noted after 1 hour and 20 hours. All samples that showed no dispersion as aggregates were re-worked and a sample placed in de-ionised water. The plates were then examined after 1 hour. Soil compaction along each pit face was measured using a pocket penetrometer, with three measurements taken at each of the five depths. Surface soil compaction was also measured with a pocket penetrometer, and six soil surface penetrations were performed at every $50 \mathrm{~cm}$ along a 3-m transect.

Soil physical and chemical properties were measured at all 20 sites, and at each of the five depths, by APAL Agricultural Laboratory (Adelaide, Australia) who analysed all soil properties according to Rayment \& Lyons (2011), as follows: soil pH was measured via the 1:5 soil water suspension method, determined after shaking for one hour at $25^{\circ} \mathrm{C}$, and the $1: 5$ soil/0.01 M calcium chloride extract method with stirring during measurement. Electrical conductivity (EC) was determined using the 1:5 soil/water extract method, using air dried ( $40^{\circ} \mathrm{C}$ ) soils shaken for 1 hour 
at $25^{\circ} \mathrm{C}$. Effective cation exchange capacity (ECEC) is the sum of exchangeable bases plus exchange acidity and was calculated as; ECEC $\left[\mathrm{cmol}_{\mathrm{c}} / \mathrm{kg}\right)=$ Exchangeable bases $\left(\mathrm{Ca}^{2+}+\mathrm{Mg}^{2+}+\mathrm{Na}^{+}+\mathrm{K}^{+}\right)+$exchange acidity $\left(\mathrm{Al}^{3+}+\mathrm{H}^{+}\right)$. Chemical components of exchangeable bases were measured using the $1 \mathrm{M}$ ammonium acetate method and exchange acidity components by the $1 \mathrm{M}$ potassium chloride method. Results were determined by atomic absorption spectrometry and reported as exchangeable cations (c.mol/kg) on an oven-dry basis. Colwell phosphorus was determined by the bicarbonate, automated colour, continuous segmented flow method (Colwell 1963). Bicarbonate-extractable $\mathrm{K}^{+}$tests were applied to measure Colwell potassium and both tests were reported as mg/kg (Rayment \& Higginson 1992). Results were determined through atomic absorption spectrometry and reported as extractable $\mathrm{K}$ and $\mathrm{P}\left(\mathrm{mg} \mathrm{kg}^{-1}\right)$ on an air-dry basis. Total nitrogen was calculated using the Dumas high temperature combustion method (Dumas 1831), using high-grade EDTA $\left(\mathrm{C}_{10} \mathrm{H}_{16} \mathrm{~N}_{2} \mathrm{O}_{8}\right)$ dried at $105^{\circ} \mathrm{C}$ for 2 hours. Mineral nitrogen, including nitrate and ammonium, was measured by the $2 \mathrm{M} \mathrm{KCl}$, automated colour, continuous segmented flow method where, and reported as $\mathrm{NH}_{4}-\mathrm{N}$ and $\mathrm{NO}_{3}-\mathrm{N}$ (mg N/kg). Total organic carbon (TOC) was determined through Dumas high-temperature combustion, which analyses the amount of $\mathrm{CO}_{2}$ liberated from combustion at $1050-1200^{\circ} \mathrm{C}$. Calcium carbonate equivalent was calculated through rapid titration, where soils treated with $1 \mathrm{M}$ Hydrochloric Acid were titrated with $0.5 \mathrm{M}$ sodium hydroxide. 
Soil samples for analysis of microbial activity were collected from the top $15 \mathrm{~cm}$ of soil at each site using a 26-mm soil auger. The auger was moved out in a spiral pattern, until 25 samples were collected at each site. Sub-samples were thoroughly mixed in buckets. Samples were sent to Microbiology Laboratories Australia Pty Ltd for a microbe activity wise (MAWS) test (Franzluebbers et al. 1996).

\section{Statistical analysis}

Differences in soil properties were tested at two levels: (1) among site types (mine path, overburden, soil stockpile, shrublands and woodlands) and (2) at a broader ecosystem level, to test for differences between reconstructed soils (mine path and overburden sites grouped) and remnant soils (shrublands and woodlands grouped). Soil stockpile sites were excluded from the ecosystem level analysis, as they did not fit either the remnant or reconstructed categories. A Kruskal-Wallis test was used to test differences among site types, and the Mann-Whitney test was used for the ecosystem-level test. To investigate the correlation between soil properties and sites, we performed correlation-based Principal Components Analyses (PCA), based on normalised data and Euclidean distance. We tested for differences between woodland and shrubland sites in mean topsoil depth, observed root zone depths, and available water using t-tests. Correlations between available water, topsoil depth and observed root zone depth, and correlations between microbial activity and time since restoration, were assessed using Pearson tests. All 
statistical analyses were performed using SPSS (IBM Corp 2017), except for PCA which was performed using CANOCO 5.0 (ter Braak \& Šmilauer 2012).

\section{Results}

Physical properties of topsoils

Fine particle content at all remnant sites showed coarse topsoil overlying finer-textured subsoil, demonstrating a highly organised soil profile (Figure S1); topsoils at these remnant sites ranged from sandy loam to sandy clay loam (10-30\% clay content) and, at depths below 85 cm, subsoils were classified as light clay or light medium clays with 35-40\% clay content. In contrast, the reconstructed soils did not demonstrate this organisation of the soil horizons; two mine path sites and two overburden sites had the largest soil particles in the profile at subsoils below $85 \mathrm{~cm}$, and all overburden sites (excluding the overburden site reconstructed in 2009) had a coarse soil texture throughout the entire profile (Figure S1). The only reconstructed site to exhibit similar distribution of particle-size content to the remnant soils was the oldest overburden site, which was reconstructed in 2009. 
Overall, soils were classified as clay loam, with a subangular blocky pedality and were prone to slaking. Across all depths, soils at woodlands, shrublands and soil stockpiles were non-dispersive or showed $<10 \%$ dispersion after 20 hours, except at two shrubland sites which had Emerson class numbers of 2 (10-50\% dispersion) and 3 (50-75\% dispersion) at 85 - $105 \mathrm{~cm}$ (Table S2). The mine path and overburden sites were nondispersive or showed $<10 \%$ dispersion after 20 hours at depths below $20 \mathrm{~cm}$, but dispersion was more variable below $20 \mathrm{~cm}$; some sites were non-dispersive, but four of the seven sites showed $>50 \%$ dispersion at one or more depths (Table S2). Subsoil horizons were classified as Bk (indicating the accumulation of calcium carbonates). Reconstructed sites contained a relatively shallow C horizon, with weakly consolidated sediments and a lack of aggregation. Topsoil depth ranged from $20-60 \mathrm{~cm}$ in woodlands, and from $15-50 \mathrm{~cm}$ in shrubland sites. Reconstructed sites had highly variable topsoil depths. Soil stockpile sites had the lowest topsoil depth, with only 10-15 cm of topsoil, which was significantly lower than observed in overburden sites $(\mathrm{p}=0.041)$.

\section{Compaction and bulk density}

Surface compaction was higher in remnant soils than in reconstructed soils (Fig. 2a). Compaction throughout the soil profile, at depths below 5 $\mathrm{cm}$, generally increased progressively with soil depth at all sites. Mean bulk density along the soil profile was generally consistent at remnant 
sites, but not at reconstructed sites or soil stockpiles (Fig. 2b). At overburden and mine path sites at $0-20 \mathrm{~cm}$, bulk density ranged from 1.64 2.28 Mg.m $\mathrm{m}^{-3}$ and 1.53 - $2.05 \mathrm{Mg} . \mathrm{m}^{-3}$ respectively. Bulk density was higher in mine path soils at depths below $35 \mathrm{~cm}$ than at all other sites.

\section{Soil chemical properties}

Soils were low in nutrients at all sites, although differences were observed among sites in the distribution of chemical properties through the soil profile (Table 1 and Table S1). All sites were very low in total organic carbon and nitrogen, and in ammonium nitrogen which was generally less $<2 \mathrm{mg} / \mathrm{kg}$. Total nitrogen, potassium and Ca:Mg generally decreased with soil depth, the latter due to an increase in magnesium with soil depth. Soils were non-saline, indicated by elctrical conductivity values below $1.5 \mathrm{dS} / \mathrm{m}$. Soil pH increased with depth and ranged from 7.6-8.4 across all sites, with topsoils and subsoils considered moderately to strongly alkaline (Wetherby 1994). Remnant and reconstructed soils varied significantly in terms of their soil chemical composition (Table 1 and Table S1). At 10-20 cm, bulk density, total organic carbon, pH, electrical conductivity, total nitrogen and calcium carbonate were significantly different among treatments (Table 1). Electrical conductivity and cation exhange capacity were generally significantly higher in mine path than woodland sites at depths between $0-45 \mathrm{~cm}$. Electrical conductivity 
(salinity; dS/m) was significantly higher in reconstructed soils at all depths from 0-75 cm (Table S1), and pH was significantly higher in mine path and overburden sites at $0-20 \mathrm{~cm}$ (Table 1).

The reconstructed soils were most easily differentiated from the remnant soils based on variables associated with salts; soil properties that were the most influential in explaining variation among treatments, as shown in the PCA diagrams (Figure S2), include cation exchange capacity

(eCEC), electrical conductivity (EC), calcium, magnesium, potassium, calcium carbonate, and pH. Remnant woodland and shrubland soils had similar soil properties, and were different from reconstructed soils, particularly at surface $(0-20 \mathrm{~cm})$ and lowest $(55-105 \mathrm{~cm})$ soil depths; remnant soils in the PCA diagrams were clustered at these depths showing greater homogeneity in soil properties compared to the reconstructed soils, which were more-widely spread across the axes at each depth.

\section{Microbial activity}

Microbial activity among the site types varied from a mean of $138.1 \pm 43.2 \mathrm{mg} \mathrm{C.kg}{ }^{-1}$ at the overburden sites to $210.0 \pm 42.0 \mathrm{mg}$ C.kg-1 $\mathrm{in}^{-1}$ the shrublands, but there were no significant differences in microbial activity among the site types $(\mathrm{F}=1.03, \mathrm{p}=0.42)$. There was no significant 
correlation between microbial activity and year since restoration for the mine path sites $(\mathrm{F}=0.28, \mathrm{p}=0.69)$ or the overburden sites $(\mathrm{F}=0.09 \mathrm{p}=$

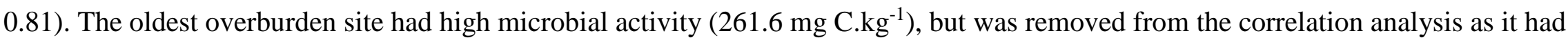
inoculates added during reconstruction.

\section{Discussion}

The aim of the study was to assess soil structure and properties in a remnant arid ecosystem, and to understand if reconstructed soil profiles after mining exhibit similar structure and properties to the remnant systems. Reconstructed sites had higher bulk density, compaction and clay content than remnant sites at topsoil depths, but this declines with soil depth. Soils from the remnant ecosystem exhibit topsoils that are coarse in texture, with clay content and compaction increasing with soil depth. Reconstructed soils differed from the remnant ecosystem in soil properties, particularly in the distribution of clay content and variables associated to the distribution of ions. Reconstructed soils were more likely to be dispersive at soil depths below $20 \mathrm{~cm}$. These results suggest that despite enormous restoration effort, the reconstructed soils have reduced ecohydrological function compared to the remnant ecosystems. 
Higher sand content in upper soil layers in arid zones is also linked to more stable soil-moisture dynamics (Zhang \& Shao 2013). Remnant soils had higher surface compaction than expected, which may increase evaporative water loss from the compacted soil surface and inhibit seedling establishment (Fan et al. 2018). Higher surface compaction in remnant soils may represent degradation from drought, the trampling effects from wildlife or, conversely, natural hydrological processes of surface soils to enhance water run-off towards vegetated patches (Tongway \& Ludwig 1990). Physical, chemical and biological crusts can influence surface compaction and subsequent hydrological processes, and are necessary to reduce soil erosion and facilitate water flows (Eldridge et al. 2002). Crust formation has been linked to soil-water retention and repellence, which drives seedling emergence in arid zones (Merino-Martína et al. 2017), however the role crusts play in controlling soil-moisture dynamics, including in a restoration setting, is complex and warrants further studies (Gypser et al. 2016).

\section{Soil reconstruction affects the distribution of properties important for plant growth}

Soil properties in the reconstructed system tended to differ to soils from remnant sites. In general, soil reconstruction increased bulk density at 10-20 cm depths. Bulk density of productive natural soils generally range from 1.1 to $1.5 \mathrm{Mg} \cdot \mathrm{m}^{-3}$, and values greater than this directly limit plant growth as most species are unable to grow roots effectively through high bulk density soils (Sheoran et al. 2010; Singh et al. 2015). The 
increased bulk density at reconstructed sites at $10-20 \mathrm{~cm}$ is likely to increase evaporative water loss and erosion potential, and will inevitably have negative impacts on establishment of woodland species (Sheoran et al. 2010). High bulk density in soils is commonly associated with disturbance and increased likelihood of desertification (Su et al. 2004). Shrestha \& Lal (2011) also showed that reclaimed soils after mining had higher bulk density than remnant systems; in their study, bulk density in the top $15 \mathrm{~cm}$ the remnant systems ranged from $0.98-1.41 \mathrm{Mg} . \mathrm{m}^{-3}$, and 1.11-1.69 Mg.m ${ }^{-3}$ in the reclaimed soils. Bulk density in the reconstructed soils in our study was $>2 \mathrm{Mg} \cdot \mathrm{m}^{-3}$ at $15 \mathrm{~cm}$ at some sites, suggesting a major impediment to root penetration. These properties are crucial factors regulating soil hydrological function, root development and plantwater uptake (Cross et al. 2018; Huang et al. 2012).

Sites containing reconstructed soils lacked a deep clay layer that is integral to reducing drainage in arid regions, and instead had high sand content at depths below $85 \mathrm{~cm}$. There is strong evidence that a clay layer at lower root zone depths strongly influences plant productivity (Macinnis et al. 2010). Other important ecosystem components that reduce deep drainage include vegetation cover and plant roots (Scanlon et al. 2005), and hence recently reconstructed soils with little vegetation structure are likely further prone to water loss from deep drainage. Many woody species in the arid zone rely on large rainfall events to recruit and grow (Wiegand et al. 2004), therefore understanding the fate of water 
following large rainfall events is important. High sand content at depths below $85 \mathrm{~cm}$ may effectively reduce the ecological impact of large rainfall events, and potentially contributes to water loss in reconstructed soils at the study site. We propose that the loss of profile organisation limits plant function and establishment at the study site.

Reconstructed soils had different chemical properties to remnant soils and these differences may impact the soil-water balance and plant soil interactions (Sheoran et al. 2010). Soil pH in reconstructed soils in this study were slightly alkaline $(\mathrm{pH}=8.0-8.4)$ at nearly all depths, because little leaching and high evaporation causes ions to concentrate in the soil (Hall et al. 2009). These thresholds are known to impede plant growth (Kopittke \& Menzies 2004), with most plants species favouring lower ranges (pH = 5.5 - 8.0) (Gazey 2018). At soil pH above 8.5, previous studies have reported soil structure degradation, reduced infiltration rates and decreased plant productivity (McCauley et al. 2017). These characteristics likely impact restoration performance in the study site, and further research should investigate ecophysiological performance of young plants. The high soil pH thresholds at reconstructed sites are likely caused by topsoil losses at all stages of soil movement around the mine. This includes initial topsoil-stripping, storage and redistribution onto rehabilitation surfaces. Topsoils are particularly susceptible to mixing with higher-pH subsoils during initial topsoil stripping prior to mining activities. Similar increases in pH and electrical conductivity were 
observed after mining in sites in Northeast America (Shrestha \& Lal 2011), and in the arid regions of China (Huang et al. 2018) and Western Australia (Cross et al. 2018), causing poor hydraulic conductivity and inhibiting plant growth.

Microbial activity in the reconstructed soils did not increase with time since reconstruction. We expected low microbial activity immediately after soil reconstruction, because when topsoil layers are removed and stockpiled during mining operations, microbial communities are buried underneath upper soil layers (Sheoran et al. 2010), which can limit soil aeration and induce anaerobic conditions (Ghose 2001). However, most studies report biocrusts - which account for much of the microbial biomass in arid soils - slowly recovering during the first 15 years of restoration (Hou et al. 2018; Zhang et al. 2016), although successional times are likely species-specific (Banning et al. 2011) and dependent on soil quality. As the age of the restoration sites increases, plant biomass and subsequent leaf litter generally increase on the soil surface. Thus, increased soil health and microbial activity are expected of older reconstructed soils (Orozco-Aceves et al. 2017). Soil moisture and nutrient content (Chandler et al. 2019), clay content and particularly soil pH (Rousk et al. 2010), are the primary factors affecting growth of biocrusts. Higher $\mathrm{pH}$ and salinity in the reconstructed soils may explain the poor microbial responses to time since restoration. Certainly, reducing runoff and increasing infiltration has been shown to facilitate the growth and restoration of important cyanobacterial crusts (Bu et al. 2014), which are 
dominant phyla across the study region (Chilton et al. 2015). The oldest overburden site (nine years) had the highest microbial activity, but was removed from the analysis as it had inoculates added during reconstruction. This may suggest there are long-term benefits to treating reconstructed soils with microbial inoculates (Muñoz-Rojas et al. 2018).

Disturbance through mining causes anomalies in soil properties and specifically, increases soil bulk density, compaction, $\mathrm{pH}$ and variables associated with salts, and reduces microbial activity. These soil properties directly affect water availability and plant-water uptake, and are key barriers to arid ecosystem restoration.

\section{Acknowledgements}

We wish to acknowledge the environmental team at Tronox Mining for funding this project, installing soil pits, and providing instrumental support and access to land. We thank Wolfgang Lewandrowski from Kings Park Science and The University of Western Australia, for providing a critical review of this manuscript. 


\section{Literature cited}

Austin A, Yahdjian L, Stark J, Belnap J, Porporato A, Norton U, Ravetta D, Schaeffer S (2004) Water pulses and biogeochemical cycles in arid and semiarid ecosystems. Oecologia, 141: 221-235

Banning N, Gleeson D, Grigg A, Grant C, Andersen G, Brodie E, Murphy D (2011) Soil microbial community successional patterns during forest ecosystem restoration. Applied and environmental microbiology, 77: 6158-6164

Belnap J, Eldridge D (2001) Disturbance and recovery of biological soil crusts. In: Belnap J, Lange O (eds) Biological soil crusts: Structure, function and management. Springer-Verlag, Heidelberg, Germany, 365-386

BOM (2018) Monthly rainfall and temperature data: Pooncarie Mail Agency. Commonwealth of Australia, Bureau of Meteorology. http://www.bom.gov.au/climate/data/. Accessed 12 Oct 2018

Bu C, Wu S, Yang Y, Zheng M (2014) Identification of factors influencing the restoration of cyanobacteria-dominated biological soil crusts. PloS one, 9 : e90049-e90049

Buelow H, Winter A, Van Horn D, Barrett J, Gooseff M, Schwartz E, Takacs-Vesbach C (2016) Microbial community responses to increased water and organic matter in the arid soils of the McMurdo Dry Valleys, Antarctica. Frontiers in microbiology, 7: 1040

This article is protected by copyright. All rights reserved. 
Carter M, Gregorich E (2007) Soil sampling and methods of analysis (2nd ed.). CRC Press, Boca Raton, FL

Chandler D, Day N, Madsen M, Belnap J (2019) Amendments fail to hasten biocrust recovery or soil stability at a disturbed dryland sandy site. Restoration Ecology, 27: 289-297

Chilton A, Woodhouse J, Neilan B (2015) Bacterial community dynamics over successional stages of Australian biological soil crusts. EGU General Assembly: Geophysical Research Abstracts, 17: EGU2015-9773:

Cleverly J, Eamus D, Restrepo Coupe N, Chen C, Maes W, Li L, Faux R, Santini N, Rumman R, Yua Q, Huete A (2016) Soil moisture controls on phenology and productivity in a semi-arid critical zone. Science of the Total Environment, 568: 1227-1237

Colwell J (1963) The estimation of the phosphorus fertiliser requirements of wheat in southern New South Wales by soil analysis. Australian Journal of Experimental Agriculture and Animal Husbandry, 3: 190-198

Cortina J, Amat B, Castillo V, Fuentes D, Maestre F, Padilla F, Rojo L (2011) The restoration of vegetation cover in the semi-arid Iberian southeast. Journal of Arid Environments, 75: 1377-1384

Crisp M (1978) Demography and survival under grazing of three Australian semi-desert shrubs. Oikos, 30: 520

Cross A, Stevens J, Sadler R, Moreira-Grez B, Ivanov D, Zhong H, Dixon K, Lambers H (2018) Compromised root development constrains the establishment potential of native plants in unamended alkaline post-mining substrates. Plant and Soil. doi:10.1007/s11104-018-3876-2

This article is protected by copyright. All rights reserved. 
Dumas J (1831) Procedes de l'analyse organic. Annals of Chemisty and Physics, 247: 198-213

Eldridge D, Zaady E, Shachack M (2002) Microphytic crusts, shrub patches, and water harvesting in the Negev desert: the Shikim system. Landscape Ecology,

17: $587-597$

Emerson W (1967) A classification of soil aggregates based on their coherence in water. Soil Research, 5: 47-57

Environdata (2019) WeatherMation Live: Historical data from Gingko weather station. Environdata. https://www.weathermation.net.au/. Accessed 15 February 2019

Fan B, McHugh A, Guo S, Ma Q, Zhang J, Zhang X, Zhang W, Du J, Yu Q, Zhao C (2018) Factors influencing the natural regeneration of the pioneering shrub Calligonum mongolicum in sand dune stabilization plantations in arid deserts of northwest China. Ecology and evolution, 8: 2975-2984

Franzluebbers A, Haney R, Hons F, Zuberer D (1996) Determination of microbial biomass and nitrogen mineralization following rewetting of dried soil. Soil Science Society of America Journal, 60: 1133-1139

Gazey C (2018) Managing soils: Soil pH. Western Australian Agriculture Authority, 2013-2018, South Perth, WA. https://www.agric.wa.gov.au/soilacidity/soil-ph

Ghose M (2001) Management of topsoil for geo-environmental reclamation of coal mining areas. Environmental Geology, 40: $1405-1410$

This article is protected by copyright. All rights reserved. 
Golos P, Dixon K (2014) Waterproofing topsoil stockpiles minimizes viability decline in the soil seed bank in an arid environment. Restoration Ecology, 22: 495-501

Griscom H, Ashton M (2011) Restoration of dry tropical forests in Central America: A review of pattern and process. Forest Ecology \& Management, 261: $1564-1579$

Gypser S, Veste M, Fischer T, Lange P (2016) Infiltration and water retention of biological soil crusts on reclaimed soils of former open-cast lignite mining sites in Brandenburg, north-east Germany. Journal of Hydrology and Hydromechanics, 64: 1-11

Hall J, Maschmedt D, Billing B (2009) The soils of southern South Australia. Department of Water, Land and Biodiversity Conservation, Adelaide Hou H, Wang C, Ding Z, Zhang S, Yang Y, Ma J, Chen F, Li J (2018) Variation in the soil microbial community of reclaimed land over different reclamation periods. Sustainability, 10: 2286

Houston J (2006) Evaporation in the Atacama Desert: An empirical study of spatio-temporal variations and their causes. Journal of Hydrology, 330: 402-412 Huang L, Baumgartl T, Mulligan D (2012) Is rhizosphere remediation sufficient for sustainable revegetation of mine tailings? Annals of botany, 110: 223-238 Huang L, Liu X, Wang Z, Liang Z, Wang M, Liu M, Suarez D (2017) Interactive effects of pH, EC and nitrogen on yields and nutrient absorption of rice (Oryza sativa L.). Agricultural Water Management, 194: 48-57

This article is protected by copyright. All rights reserved. 
Huang Y, Kuang X, Cao Y, Bai Z (2018) The soil chemical properties of reclaimed land in an arid grassland dump in an opencast mining area in China. RSC Advances, 8: 41499-41508

IBM Corp (2017) IBM SPSS Statistics for Windows, Version 25.0. IBM Corp., Armonk, NY

Isbell R, NCST (2016) The Australian soil classification. Second edn. National Committee on Soil and Terrain, CSIRO Publishing, Clayton South, VIC, Australia James J, Sheley R, Erickson T, Rollins K, Taylor M, Dixon K (2013) A systems approach to restoring degraded drylands. Journal of Applied Ecology, 50: 730739

Johnson B, Verburg G, Arnone P (2016) Plant species effects on soil nutrients and chemistry in arid ecological zones. Oecologia, 182: 299-317 Kassas M (1995) Desertification: a general review. Journal of arid environments, 30: 115-128

Kopittke P, Menzies N (2004) Control of nutrient solutions for studies at high pH. Plant and Soil, 266: 343-354

Lau J, Lennon J (2012) Rapid responses of soil microorganisms improve plant fitness in novel environments. Proceedings of the National Academy of Sciences of the United States of America, 109: 14058-14062

Lawrence C (1966) Cainozoic stratigraphy and structure of the Mallee region, Victoria. Proceedings of the Royal Society of Victoria, 79: 517-553

Macinnis C, Fuentes S, O'Grady A, Palmer A, Taylor D, Whitley R, Yunusa I, Zeppel M, Eamus D (2010) Root biomass distribution and soil properties of an open woodland on a duplex soil. Plant and Soil, 327: 377-388

This article is protected by copyright. All rights reserved. 
Maestre F, Bowker M, Escolar C, Puche M, Soliveres S, Maltez-Mouro S, García-Palacios P, Castillo-Monroy A, Martínez I, Escudero A (2010) Do biotic interactions modulate ecosystem functioning along stress gradients? Insights from semi-arid plant and biological soil crust communities. Philosophical Transactions of the Royal Society of London Series B, Biological Sciences, 365: 2057-2070

Maestre F, Eldridge D, Soliveres S, Kéfi S, Delgado-Baquerizo M, Bowker M, García-Palacios P, Gaitán J, Gallardo A, Lázaro R, Berdugo M (2016) Structure and functioning of dryland ecosystems in a changing world. Annual review of ecology, evolution, and systematics, 47: 215-237

McCauley A, Jones C, Olson-Rutz K (2017) Soil pH and organic matter. Nutrient Management Module No 8, Montana State University Extension, Bozeman, MT: 1-16. http://landresources.montana.edu/nm/documents/NM8.pdf

Merino-Martína L, Commander L, Mao Z, Stevens J, Miller B, Golos P, Mayence CE, Dixon K (2017) Overcoming topsoil deficits in restoration of semiarid lands: Designing hydrologically favourable soil covers for seedling emergence. Ecological Engineering, 105: 102-117

Moreira-Grez B, Muñoz-Rojas M, Kariman K, Storer P, O’Donnell A, Kumaresan D, Whiteley A (2019) Reconditioning degraded mine site soils with exogenous soil microbes: Plant fitness and soil microbiome outcomes. Frontiers in Microbiology, 10. doi:10.3389/fmicb.2019.01617

Muñoz-Rojas M, Román J, Roncero-Ramos B, Erickson T, Merritt D, Aguila-Carricondo P, Cantón Y (2018) Cyanobacteria inoculation enhances carbon sequestration in soil substrates used in dryland restoration. Science of the Total Environment, 636: 1149-1154

This article is protected by copyright. All rights reserved. 
Muñoz-Rojas M, Erickson T, Dixon K, Merritt D (2016) Soil quality indicators to assess functionality of restored soils in degraded semiarid ecosystems.

Restoration Ecology, 24: S43-S52

Noy-Meir I (1973) Desert ecosystems: environment and producers. Annu Rev Ecol Syst, 4: 25-52

Orozco-Aceves M, Tibbett M, Standish R (2017) Correlation between soil development and native plant growth in forest restoration after surface mining. Ecological Engineering, 106: 209-218

Pickup G, Stafford Smith D (1993) Problems, prospects and procedures for assessing the sustainability of pastoral land management in arid Australia. Journal of Biogeography, 20: 471-487

Ravi S, Breshears D, Huxman T, D’Odorico P (2010) Land degradation in drylands: interactions among hydrologic-aeolian erosion and vegetation dynamics. Geomorphology, 116: 236-245

Rayment G, Higginson F (1992) Australian laboratory handbook of soil and water chemical methods. Inkata Press, Port Melbourne, Australia Rayment G, Lyons D (2011) Soil chemical methods: Australasia. CSIRO Publishing, Collingwood, VIC

Rousk J, Bååth E, Brookes P, Lauber C, Lozupone C, Caporaso J, Knight R, Fierer N (2010) Soil bacterial and fungal communities across a pH gradient in an arable soil. The Isme Journal, 4: 1340-1351

Sala O, Parton W, Joyce L, Lauenroth W (1988) Primary production of the central grassland region of the United States. Ecology, 69: 40-45

This article is protected by copyright. All rights reserved. 
Scanlon B, Reedy R, Keese K, Dwyer S (2005) Evaluation of evapotranspiration covers for waste containment in arid and semi-arid regions in south-western USA. Vadose Zone Journal, 4: 55-71

Schwinning S, Sala O (2004) Hierarchy of responses to resource pulses in arid and semi-arid ecosystems. Oecologia, 141: 211-220

Sheoran V, Sheoran A, Poonia P (2010) Soil reclamation of abandoned mine land by revegetation: A review. International Journal of Soil, Sediment and Water, 3: 1-21

Shrestha R, Lal R (2011) Changes in physical and chemical properties of soil after surface mining and reclamation. Geoderma, 161: 168-176

Simmers I (2003) Understanding water in a dry environment: IAH International Contributions to Hydrogeology vol 23. Swets and Zeitlinger B.V., Lisse, The Netherlands

Singh J, Salaria A, Kaul A (2015) Impact of soil compaction on soil physical properties and root growth: A review. International Journal of Food, Agriculture and Veterinary Sciences, 5: 23-32

Sluiter I, Schultz N (2017) Rehabilitation report on 2017 monitoring of revegetation at the Ginkgo Mineral Sands Mine. Ogyris Pty. Ltd. and Cristal Mining Australia Ltd, Merbein, VIC

Su R, Zhao H, Zhang T (2004) Fractal features of soil particle size distribution and the implication for indicating desertification. Geoderma, 122: 43-49

ter Braak C, Šmilauer P (2012) Canoco reference manual and user's guide: software for ordination, version 5.0. Microcomputer power, Ithaca, NY, USA

This article is protected by copyright. All rights reserved. 
Tongway D, Ludwig J (1990) Vegetation and soil patterning in semi-arid mulga lands of Eastern Australia. Australian Journal of Ecology, 15: 23-34

van der Putten W, Bardgett R, Bever J, Bezemer T, Casper B, Fukami T, Kardol P, Klironomos J, Kulmatiski A, Schweitzer J, Suding K, van de Voorde T, Wardle D (2013) Plant-soil feedbacks: the past, present andfuture challenges. J Ecol, 101: 265-276

Walsh N (1996) Chenopodiaceae. In: Walsh N, Entwisle T (eds) Flora of Victoria. Dicotyledons Winteraceae to Myrtaceae, vol 3. Inkata Press, Melbourne, Wang T (2004) Study on sandy desertification in China: 4. Strategy and approach for combating sandy desertification. Journal of Desert Research, 24: 115123

Wetherby K (1994) Soil description book. Revised edn edn. Cleve Research Laboratories and SA Department of Agriculture, Cleve, Australia Wiegand K, Jeltsch F, Ward D (2004) Minimum recruitment frequency in plants with episodic recruitment. Oecologia, 141: 363-372

Zhang C, Liu G, Xue S, Wang G (2016) Soil bacterial community dynamics reflect changes in plant community and soil properties during the secondary succession of abandoned farmland in the Loess Plateau. Soil Biology and Biochemistry, 97: 40-49

Zhang P, Shao M (2013) Temporal stability of surface soil moisture in a desert area of northwestern China. Journal of Hydrology, 505: 91-101

This article is protected by copyright. All rights reserved. 


\section{Tables (1)}

Table 1: Soil physico-chemical properties at different soil depths $( \pm$ standard errors $) . \mathrm{BD}=$ bulk density $\left(\mathrm{Mg} \cdot \mathrm{m}^{-3}\right), \mathrm{Moisture}=(\%), \mathrm{TOC}=$ total organic carbon $(\%)$, $\mathrm{pH}=\mathrm{pH}$ level following CaCl2, EC = electrical conductivity (dS/m), eCEC = effective cation exchange capacity (c.mol/kg), Na = Sodium (mg/kg), Nitrate N = nitrate nitrogen

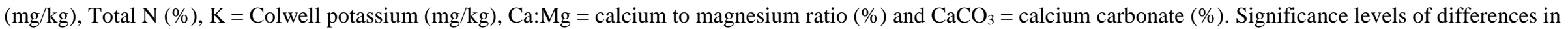
soil properties at the site level, and at the ecosystem level, are indicated by $\mathrm{p}$ values; n.s. when $\mathrm{p}>0.05$, $*$ when $0.05>\mathrm{p}>0.01, * *$ when $0.01>\mathrm{p}>0.001$, *** when $\mathrm{p}<$ 0.001. Sites that share a letter ( $a$ or $b$ ) share similar soil properties. Soil properties at depths below $20 \mathrm{~cm}$ are shown in Table S1.

\begin{tabular}{|c|c|c|c|c|c|c|c|c|c|c|c|c|}
\hline & $\begin{array}{c}\text { BD } \\
\left({\left.\mathrm{Mg} \cdot \mathrm{m}^{-3}\right)}^{-}\right.\end{array}$ & $\begin{array}{c}\text { Moisture } \\
(\%)\end{array}$ & $\begin{array}{l}\text { TOC } \\
(\%)\end{array}$ & pH & $\begin{array}{c}\mathrm{EC} \\
(\mathrm{dS} / \mathrm{m})\end{array}$ & $\begin{array}{c}\text { eCEC } \\
\text { (c.mol/kg) }\end{array}$ & $\begin{array}{c}\mathrm{Na} \\
(\mathrm{mg} / \mathrm{kg})\end{array}$ & $\begin{array}{c}\text { Nitrate N } \\
\text { (mg/kg) }\end{array}$ & $\begin{array}{c}\text { Total N } \\
(\%)\end{array}$ & $\begin{array}{c}\mathrm{K} \\
(\mathrm{mg} / \mathrm{kg})\end{array}$ & $\begin{array}{l}\text { Ca:Mg } \\
(\%)\end{array}$ & $\begin{array}{c}\mathrm{CaCO}_{3} \\
(\%)\end{array}$ \\
\hline \multicolumn{13}{|l|}{$0-10 \mathrm{~cm}$} \\
\hline Woodland & $1.62 \pm 0.09$ & $1.7 \pm 0.9$ & $0.49 \pm 0.14$ & $7.6 \pm 0.1 a$ & $0.13 \pm 0.03$ & $14.7 \pm 3.2 a$ & $44 \pm 6$ & $11.6 \pm 3.1$ & $0.06 \pm 0.01$ & $342 \pm 41$ & $5.57 \pm 1.26$ & $2.4 \pm 1.4$ \\
\hline Shrubland & $1.56 \pm 0.08$ & $1.2 \pm 0.1$ & $0.48 \pm 0.04$ & $7.9 \pm 0.1 a b$ & $0.12 \pm 0.01$ & $20.7 \pm 2.3 a b$ & $65 \pm 25$ & $13.8 \pm 0.6$ & $0.11 \pm 0.01$ & $496 \pm 45$ & $8.07 \pm 1.62$ & $2.9 \pm 1.1$ \\
\hline Mine path & $1.58 \pm 0.03$ & $1.5 \pm 0.4$ & $0.53 \pm 0.16$ & $8.0 \pm 0.1 a b$ & $0.33 \pm 0.05$ & $29.9 \pm 1.76 b$ & $752 \pm 378$ & $22.3 \pm 3.8$ & $0.04 \pm 0$ & $317 \pm 52$ & $8.03 \pm 1.84$ & $5.1 \pm 2.5$ \\
\hline Overburden & $1.8 \pm 0.06$ & $1.7 \pm 0.6$ & $0.22 \pm 0.06$ & $8.0 \pm 0.03 b$ & $0.27 \pm 0.12$ & $20.2 \pm 1.3 a b$ & $510 \pm 367$ & $22.8 \pm 7.8$ & $0.08 \pm 0.01$ & $473 \pm 102$ & $11.18 \pm 2.36$ & $2.9 \pm 1.5$ \\
\hline Soil stockpile & $1.57 \pm 0.08$ & $1.8 \pm 0.4$ & $0.42 \pm 0.11$ & $8.0 \pm 0.1 a b$ & $0.23 \pm 0.04$ & $27.7 \pm 0.9 a b$ & $362 \pm 137$ & $17.7 \pm 2.8$ & $0.04 \pm 0.01$ & $287 \pm 26$ & $8.61 \pm 1.9$ & $11.3 \pm 1.9$ \\
\hline \multicolumn{13}{|l|}{ ANOVA } \\
\hline $\begin{array}{l}\text { Site level } \\
\text { Ecosystem level }\end{array}$ & $\begin{array}{l}\text { n.s. } \\
\text { n.s. }\end{array}$ & $\begin{array}{l}\text { n.s. } \\
\text { n.s. }\end{array}$ & $\begin{array}{l}\text { n.s. } \\
\text { n.s. }\end{array}$ & * & $\begin{array}{c}\text { n.s. } \\
*\end{array}$ & $\begin{array}{c}* \\
\text { n.s. }\end{array}$ & $\begin{array}{c}\text { n.s. } \\
*\end{array}$ & $\begin{array}{c}\text { n.s. } \\
*\end{array}$ & $\begin{array}{l}\text { n.s. } \\
\text { n.s. }\end{array}$ & $\begin{array}{l}\text { n.s. } \\
\text { n.s. }\end{array}$ & $\begin{array}{l}\text { n.s. } \\
\text { n.s. }\end{array}$ & $\begin{array}{l}\text { n.s. } \\
\text { n.s. }\end{array}$ \\
\hline \multicolumn{13}{|l|}{$10-20 \mathrm{~cm}$} \\
\hline Woodland & $1.63 \pm 0.06 a b$ & $1.3 \pm 0.2$ & $0.52 \pm 0.1 a$ & $7.76 \pm 0.09 a$ & $0.11 \pm 0.01 a$ & $16.17 \pm 4.09$ & $88 \pm 23$ & $11 \pm 2.7$ & $0.05 \pm 0.013 a b$ & $260 \pm 28$ & $6.76 \pm 1.67$ & $3 \pm 2.3 a$ \\
\hline Shrubland & $1.52 \pm 0.02 a b$ & $2.5 \pm 0.5$ & $0.29 \pm 0.09 a b$ & $7.97 \pm 0.04 a b$ & $0.12 \pm 0.01 a b$ & $24.62 \pm 1.46$ & $947 \pm 518$ & $13 \pm 0.6$ & $0.1 \pm 0.007 a$ & $330 \pm 73$ & $8.51 \pm 1.95$ & $7.8 \pm 2.3 a b$ \\
\hline Mine path & $1.81 \pm 0.13 a b$ & $2.6 \pm 0.1$ & $0.31 \pm 0.02 a b$ & $8.1 \pm 0.08 a b$ & $0.36 \pm 0.05 b$ & $29.96 \pm 0.89$ & $1308 \pm 478$ & $17.7 \pm 1.3$ & $0.03 \pm 0.003 b$ & $257 \pm 13$ & $6.27 \pm 0.82$ & $11 \pm 0.6 a b$ \\
\hline
\end{tabular}

This article is protected by copyright. All rights reserved. 
Overburden

$1.97 \pm 0.14 a \quad 1.3 \pm 0.4$

Soil stockpile

$1.31 \pm 0.04 b \quad 3.5 \pm 1.5$

$0.05 \pm 0.01 b \quad 8.12 \pm 0.03 b \quad 0.16 \pm 0.04 a b \quad 20.27 \pm 0.61$

$\begin{array}{llll}0.86 \pm 0.27 a & 8.07 \pm 0.06 a b & 0.29 \pm 0.02 a b & 28.7 \pm 1.58\end{array}$

$558 \pm 471$

$13.5 \pm 2.3 \quad 0.08 \pm 0.003 a b \quad 333 \pm 20$

$832 \pm 312$

$24 \pm 11.1 \quad 0.05 \pm 0.006 a b \quad 197 \pm 54$

$9.06 \pm 0.83 \quad 2.3 \pm 1.4 a b$

ANOVA

$\begin{array}{ll}* * & \text { n.s. } \\ * * & \text { n.s. }\end{array}$

*

**

$\begin{array}{ll}* & \text { n.s. } \\ * & \text { n.s. }\end{array}$

n.s.

n.s

n.s.

$*$
n.s.

n.s.

n.s.

(n)

This article is protected by copyright. All rights reserved. 


\section{Figures}

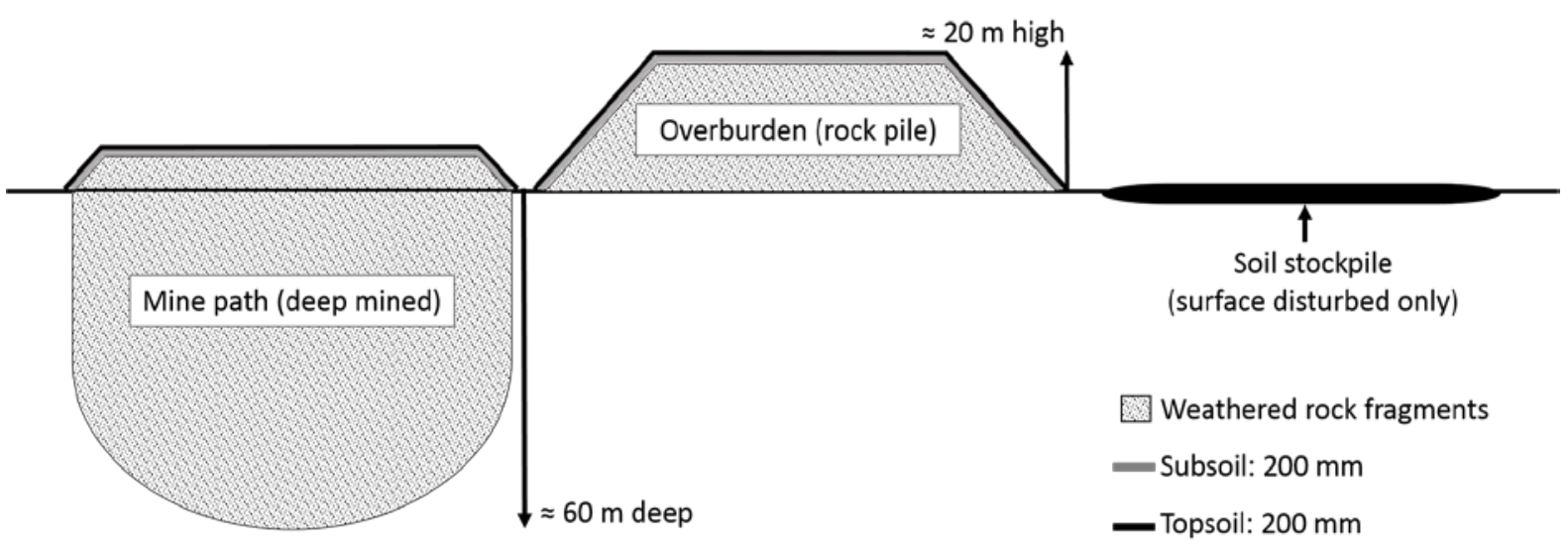

Fig. 1: Soil profile types at the study site. Mine path sites were excavated then filled with rock fragments and topped with subsoil and topsoil. Overburden sites are mountains of excess rock fragments topped with subsoil and topsoil. Soil stockpiles are where top soils is temporarily stored until they are returned to mine path and overburden sites, which disturbs the original vegetation and topsoil. 
(a) Compaction $\left(\mathrm{kg} / \mathrm{cm}^{2}\right)$

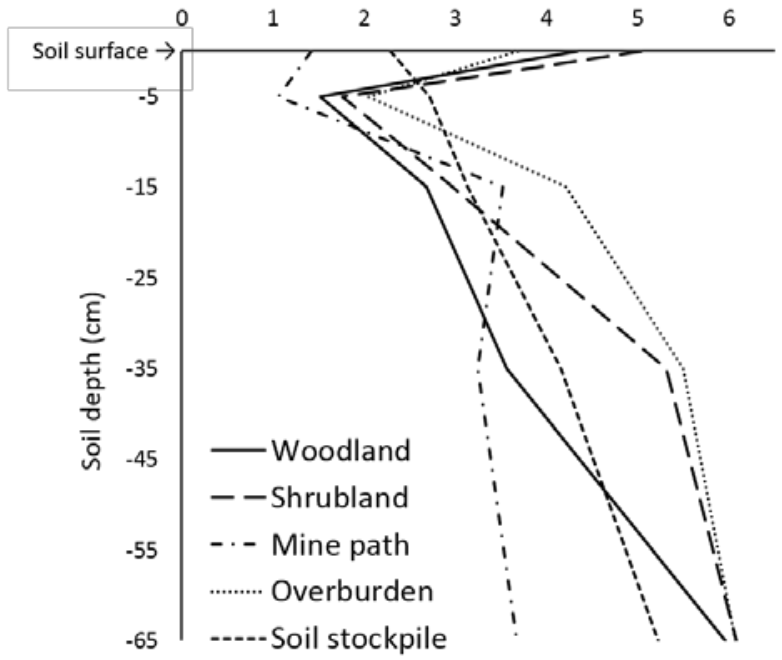

(b) Bulk density $\left(\mathrm{Mg} \cdot \mathrm{m}^{-3}\right)$

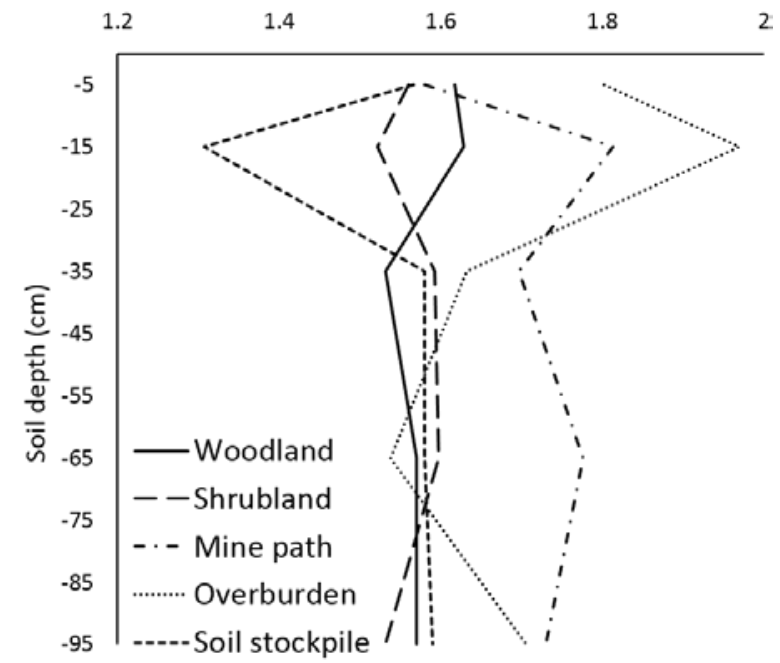

Fig. 2: (a) mean compaction and (b) mean bulk density across all sites. Compaction below 65 cm exceeded the maximum reading of the penetrometer at most sites Error bars have been omitted to improve visualisation; standard errors for mean bulk density are presented in Table 1 and Table S1. 


\section{University Library}

\section{- M M N E R VA A gateway to Melbourne's research publications}

Minerva Access is the Institutional Repository of The University of Melbourne

Author/s:

Duncan, C;Good, MK;Sluiter, I;Cook, S;Schultz, NL

Title:

Soil reconstruction after mining fails to restore soil function in an Australian arid woodland

Date:

2020-06-01

Citation:

Duncan, C., Good, M. K., Sluiter, I., Cook, S. \& Schultz, N. L. (2020). Soil reconstruction after mining fails to restore soil function in an Australian arid woodland. Restoration Ecology, 28 (S1), pp.A35-A43. https://doi.org/10.1111/rec.13166.

Persistent Link:

http://hdl.handle.net/11343/275552 